UNDERGRADUATE RESEARCH IN NATURAL AND CLINICAL SCIENCE AND TECHNOLOGY (URNCST) JOURNAL Read more URNCST Journal articles and submit your own today at: https://www.urncst.com

\title{
Investigation into Cannabidiol as a Potential Treatment for Preeclampsia in B6D2F1 Mice with Placenta Specific Human Transgene hsFLT1: A Research Protocol
}

\author{
Madison A. Best, BSc Student [1]*, Rachel A. Wilkes, BSc [2], \\ Nicholas M.R. Zingone, BSc Student [3], Hesham Farag, BSc [2]
}

[1] Department of Molecular and Cellular Biology, University of Guelph, Guelph, ON, Canada, N1G 2W1

[2] Department of Human Health and Nutritional Sciences, University of Guelph, Guelph, ON, Canada, N1G 2W1

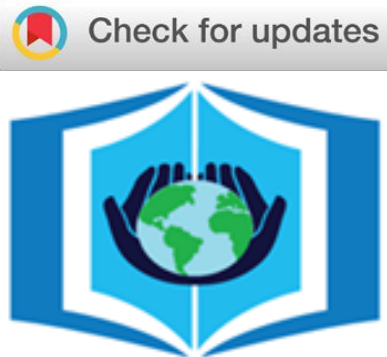

URNCST Journal

"Research in Earnest"

[3] Department of Biological Sciences, University of Guelph, Guelph, ON, Canada, N1G 2W1

*Corresponding Author: mbest02@uoguelph.ca

\begin{abstract}
Preeclampsia is a common pregnancy complication that leaves the affected individual to choose between preterm delivery or risking death. These outcomes are far from ideal and the search for a better treatment is underway. Previous studies have implicated whole flower commercial cannabis use as a risk factor for the development of preeclampsia as well as other partum complications. However, commercial cannabis is high in $\Delta 9$-Tetrahydrocannabinol and other psychoactive cannabinoids and low in cannabidiol. Therefore, it is imperative that the use of isolated CBD as a potential therapy is investigated. In this study novel mouse models of preeclampsia will be utilized to demonstrate the effect of cannabidiol on expecting mothers who are predisposed to preeclampsia. This will be demonstrated using B6D2F1 mice with placenta specific human transgene $h s F L T 1$ to simulate preeclampsia. Cannabidiol will be introduced at different stages of gestation and symptoms of preeclampsia will be measured through blood pressure, protein urine content, and fetal mortality rate. The group with mice receiving cannabidiol prior to implantation are anticipated to show the lowest incidences of preeclampsia symptoms. With so many studies suggesting cannabidiol as a treatment method for a variety of the most dangerous symptoms of preeclampsia, it may be possible that cannabis will allow future mothers afflicted with Preeclampsia to bring their child to full-term.
\end{abstract}

Keywords: anti-inflammatory; hypertension; preeclampsia; pregnancy; proteinuria; trophoblast

\section{Introduction}

Preeclampsia (PE) is a gestational condition characterized by the onset of hypertension $(\geq 140 \mathrm{mmHg}$ systolic or $\geq 90$ diastolic), proteinuria, and other vascular dysfunctions [1]. The onset of seizures re-characterizes the condition as the more severe eclampsia, which often results in death from stroke [1]. PE affects $10 \%$ of pregnancies worldwide and accounts for $42 \%$ of maternal deaths [2]. Children born after a pregnancy complicated by preeclampsia have an average of $5 \%$ and as high as $23 \%$ lower birth weight than those born after uncomplicated pregnancies. Additionally, the risk of stillbirth is seven-fold higher compared to normotensive pregnancies [3]. The primary risk factors are advanced age, chronic hypertension, and renal disease. A few potential treatments for the root causes of preeclampsia are in preliminary stages, such as the use of nanomedicine [4]. However, nanomedicine can be expensive due to low current demand and lack of presence in large pharmaceutical companies [5]. Presently there are only treatments for the symptoms of preeclampsia. Magnesium sulfate has been used as a seizure prophylaxis; this will prevent the negative impacts of maternal seizing on the fetus [6]. However, this treatment has also been associated with dangers including increased postpartum bleeding, increased respiratory depression and decreased neuromuscular transmission [6]. Therefore, birth is the only clinical treatment currently available, which is less than ideal if symptoms present early in pregnancy.

The best way to treat the root cause of preeclampsia is to investigate the underlying mechanisms involved. The current accepted mechanism for the development of PE begins with the shallow invasion of trophoblast cells into the placenta. Decidualization is a process involving the transformation of maternal tissues into a decidua, responsible for producing immune cells that assist in trophoblast implantation [7]. When an imbalance of these immune cells exists, the implantation of the trophoblast may be too shallow. Shallow implantation inhibits the proper formation of blood vessels, called the spiral arteries, which if incorrectly formed will ultimately become fibrous [8]. These fibrous spiral arteries cause the fetal ischaemia that is responsible for an increased pro-inflammatory cytokine response and immune imbalance. 
UNDERGRADUATE RESEARCH IN NATURAL AND CLINICAL SCIENCE AND TECHNOLOGY (URNCST) JOURNAL Read more URNCST Journal articles and submit your own today at: https://www.urncst.com

Chronic maternal inflammation caused by these cytokines causes maternal endothelial damage. Tumor necrosis factor alpha TNF- $\alpha$ release decreases nitric oxide synthesis, and in turn increases vasoconstrictor synthesis, resulting in hypertension [7]. Angiotensin II autoantibody production and reactive oxygen species generation additionally contribute to the development of hypertension in PE [7]. The use of IV antihypertensives such as labetalol are currently used to treat severe hypertension, however, use is limited due to potential teratogenic effects [8].

Despite cannabis use showing lower birth weight, no prolonged impairments to the child have been characterized. This in part due to the limitations of observational studies considering the confounding effects of co-consumption of tobacco and alcohol making it difficult to identify outcomes of exclusively cannabis use [9].

Although there is a negative association between cannabis and pregnancy, CBD may have therapeutic benefits due to its downstream effects counteracting the negative maternal symptoms of PE [10]. These effects include: anti-inflammation, vasodilation/hypertension [10, 11]. The increased stimulation of cannabinoid receptor type $1\left(\mathrm{CB}_{1}\right)$ was shown to result in improper trophoblast implantation and could be a risk factor for PE [12]. THC is the primary agonist of $\mathrm{CB}_{1}$, and causes inflammation, oxidative stress and fibrosis when activated in vascular endothelial and smooth muscle cells [13]. The anti-inflammatory properties of CBD are seen through its activity as a partial agonist of the PPAR $\gamma$ receptor. PPAR $\gamma$ ligands both inhibit pro-inflammatory cytokines and increase anti-inflammatory cytokines [14]. In PE, placental ischemia generates an improper immune response resulting in the increased release of proinflammatory cytokines (TNF- $\alpha$, IL-6 and IL-17). This leads to chronic maternal inflammation. Normal, non-hypertensive pregnancies involve an increase in innate immune cells in the periphery and a decrease in inflammatory cells such as dendritic cells and natural killer cells [7]. By decreasing the levels of cytokines, CBD may help prevent endothelial damage that leads to hypertension.
Further, CBD decreases the effects of vasoconstriction agents and enhances the effects of vasodilation agents [15]. One of the largest dangers to maternal health is the constriction of blood vessels that leads to hypertension. CBD could alleviate this potentially fatal symptom, allowing the mother to carry the child to term safely. Can CBD be utilized as a therapeutic treatment for PE by reducing the fatal symptoms associated with the disease, allowing the mother to carry their offspring to term?

\section{Methods \\ The Animals}

Two-month-old female B6D2F1 mice with placenta specific human transgene $h s F L T 1$ [16]. Mated with twomonth-old B6D2F1 male mice. Mice will we be kept in well ventilated cages with 12-hour dark light cycles and have free access to water and food [17].

Pre-Experimental Measurements

After 30 days, an enzyme linked immunosorbent assay (ELISA) will be utilized to measure $h s F L T 1$ quantity in each mouse [18]. All mice negative for $h s F L T 1$ expression will be removed from the study without replacement. With the recursive Extreme Studentized Deviate (ESD) outlier detection procedure at $\alpha=0.05$ any outliers in $h s F L T$ expression will be removed without replacement [19].

Exposure Groups

Approximately forty $(n=40)$ adult female mice will be placed into a negative and positive control, and five treatment groups. The negative and positive controls will both have zero exposure to $\mathrm{CBD}$ with the negative control containing the $h s F L T 1$ placental transgene and the positive control without the transgene. Group 1 will begin CBD intake at the onset of CBD symptoms until symptoms subside. Group 2 also begins CBD intake at the onset of symptoms but will continue intake through to the end of pregnancy. Group 3 will intake CBD from impregnation to the end of pregnancy. Group 4 will and 5 will begin CBD 25-35 days prior to impregnation, group 4 will end intake prior to anticipated impregnation and group 5 will continue through to the end of pregnancy.

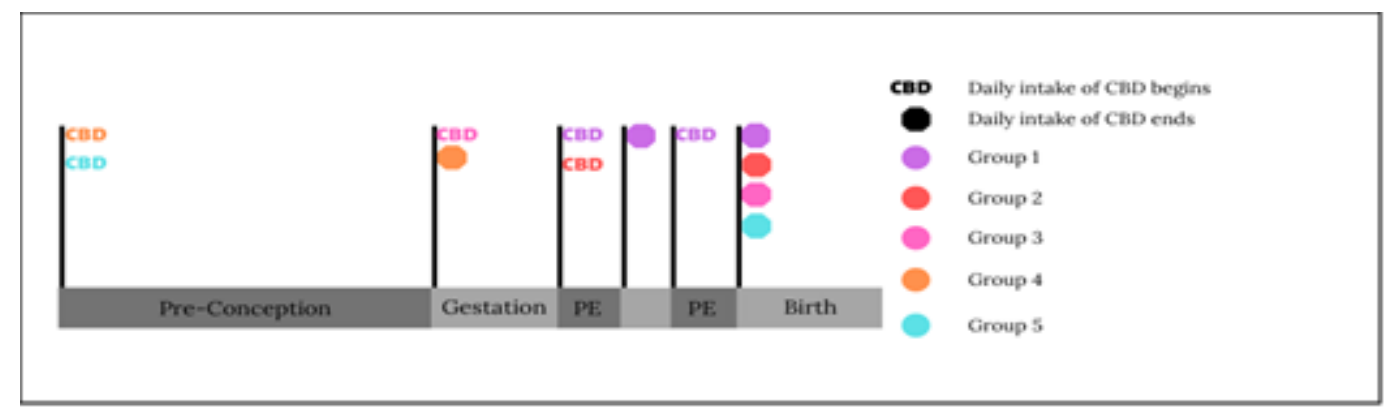

Figure 1: Timeline representing the point during trial that each test group beings and ends the intake of CBD. Group 1 is portrayed in purple, group 2 in red, group 3 in pink, group 4 in orange, and group 5 in blue. Where the CBD symbol appears in the timeline this indicates when specific group begins CBD intake. The hexagons indicate when that specific group ceases CBD intake along the timeline. 
UNDERGRADUATE RESEARCH IN NATURAL AND CLINICAL SCIENCE AND TECHNOLOGY (URNCST) JOURNAL Read more URNCST Journal articles and submit your own today at: https://www.urncst.com

\section{Treatment Timeline}

Treatment with CBD will begin in groups 4 and 5 at day (-) 30 (D-30). Negative and positive controls as well as groups 1-3 will consume a placebo pill D-30. All consumption CBD or placebo will occur at 7 PM daily.

Blood pressure (BP) will be measured through the tail cuff method at 7 AM daily, a measurement above $200 \mathrm{mmHg}$ systolic will be considered hypertensive and define the onset of PE [20]. Mice will be monitored by video for seizures, onset will be considered progression to eclampsia. On D-5 individuals from all groups will be caged with a male counterpart. On D-5 group 3 stop placebo treatment and begin CBD treatment. Group 4 will cease CBD consumption and begin placebo and begin intake of CBD.

D 0 will be defined as the appearance of the vaginal plug and mice will be removed from the male counterpart and placed into separate cages. Mice that fail to become pregnant will be excluded without replacement.

When the blood pressure of mice in groups 1 and 2 exceed $200 \mathrm{mmHg}$ they will cease placebo intake and begin CBD intake. Group 1 will cease resume placebo intake and cease CBD intake when blood pressure is below $200 \mathrm{mmHg}$ systolic.

From D 15 to D 25 once the female mice give birth they will be collected and each mouse placed in a metabolic cage for 24-hours. Total protein urine will be determined by the Bradford assay, and then protein concentration will be multiplied by total urine volume to determine 24-hr urine excretion [20]. Final BP measurements of both the mothers and the pups will be conducted 3-5 days following birth before cortical development occurs [21]. Following procedures outlined by the American Veterinary Medical Association Guidelines for the Euthanasia of Animals, all the mice will be sacrificed to assess the impacts of each of the defined groups through histological studies [22].

Statistical Analysis

After data is collected, statistical significance will be analysed using R. A post-hoc ANOVA f test will be constructed using the means of total urine protein levels, number of pre-eclamptic episodes and total number of cases that progress to eclampsia to test the null hypothesis $\mathrm{H} 0$ : $\mu 1=\mu 2=\mu 3=\mu 4=\mu 5=\mu 6$ against the alternate hypothesis H1: Not all means are equal. A two sample T-test comparing the percentage of pregnancies that result in death of each test group against the negative control at $95 \%$ confidence [19].

\section{Results}

We predict that the group receiving CBD at least from impregnation all the way until the end of pregnancy will show the lowest blood pressure and highest delivery success rate. This is based on CBD being administered prior to implantation so it can prevent improper trophoblast implantation increasing the chances of no preeclampsia onset. This would be seen in groups 3 and 5 .
Further, we predict groups that have CBD administered once the preeclampsia symptom of high blood pressure presents, will have reduced blood pressure. However, it is possible these mice will still show proteinuria post-partum, this effect likely seen higher in group 1 rather than 2, as group 1 allows for the recurrence of high blood pressure.

Lastly, we predict that group 4 will have high blood pressure, high protein urine content, and high fetal mortality. Results are likely to be similar to the control as CBD may not stay in the system for very long. However, if maintained in the system may aid in proper trophoblast implantation.

\section{Discussion}

Results will be analysed per the statistical analysis covered in the methodology. High blood pressure will determine the onset of preeclampsia. Severity of symptoms will be quantified with blood pressure, urine protein levels, and fetal survival. Blood pressure, protein levels, and fetal mortality rates significantly higher than positive control mice and significantly similar to the negative control mice will indicate unsuccessful treatment groups. Blood pressure, protein levels, and fetal mortality rates significantly lower than negative control mice and significantly similar to the positive control mice will indicate successful treatment groups.

\section{Conclusions}

Through publishing this protocol, we aim to broaden the field of cannabis study as it pertains to incurable conditions such as preeclampsia. The use of cannabidiol as a therapy for preeclampsia could have a large impact on obstetrics, potentially reducing maternal deaths by close to half and decreasing the rate of preterm births. Future directions would encompass finding ideal drug doses for successful groups. Should these experiments move forward onto human trials, some group test trials investigated in this protocol may not be realistic for the human experience. Since preeclampsia is an unpredictable condition, and often has a sudden onset, the results from the group receiving $\mathrm{CBD}$ at the onset of preeclampsia until the end of pregnancy may be the most significant and transferrable, especially until the effects of CBD during pregnancy have yet to be fully elucidated.

\section{List of Abbreviations}

ANOVA: analysis of variance

BP: blood pressure

$\mathbf{C B}_{1}$ : cannabinoid receptor type 1

CBD: Cannabidiol

ELISA: enzyme-linked immunosorbent assay

ESD: extreme studentized deviate

PE: preeclampsia

THC: $\Delta$ 9-Tetrahydrocannabinol

TNF- $\alpha$ : tumor necrosis factor alpha 
UNDERGRADUATE RESEARCH IN NATURAL AND CLINICAL SCIENCE AND TECHNOLOGY (URNCST) JOURNAL Read more URNCST Journal articles and submit your own today at: https://www.urncst.com

\section{Conflicts of Interest}

The authors declare that they have no conflict of interests.

Ethics Approval and/or Participant Consent

This is a proposed protocol therefore it has yet to gain ethics approval. Considering the use of live animals prior to execution of this experiment ethics approval is essential.

\section{Authors' Contributions}

MAB: made contributions to the design of the study, collected and analysed literature data, revised the manuscript critically, gave final approval of the version to be published, and agrees to be accountable for all aspects of the work.

RAW: made contributions to the design of the study, collected and analysed literature data, revised the manuscript critically, gave final approval of the version to be published, and agrees to be accountable for all aspects of the work.

NMRZ: made contributions to the design of the study, collected and analysed literature data, revised the manuscript critically, gave final approval of the version to be published, and agrees to be accountable for all aspects of the work.

HF: made contributions to the design of the study, collected and analysed literature data, revised the manuscript critically, gave final approval of the version to be published, and agrees to be accountable for all aspects of the work.

\section{Funding}

Special thanks to the College of Biological Sciences Student Council for providing funding for publication.

\section{References}

[1] Sones JL, Davisson RL. Preeclampsia, of mice and women. Physiol. Genomics. 2016 Aug 1; 48(8): 565-572. https://dx.doi.org/10.1152/ physiolgenomics.00125.2015

[2] Grill S, Rusterholtz C, Zanetti-Dällenbach R, Tercanli S, Holzgreve W, Hahn S, Lapaire O. Potential markers of preeclampsia-a review. Reprod. Biol Endocrinol. 2009 Jul 14; 7(70). https://dx.doi.org/10.1186/1477-7827-7-70

[3] Bokslag A, van Weissenbruch M, Mol BW, de Groot CJM. Preeclampsia; short and long-term consequences for mother and neonate. Early Hum. Dev. 2016 Nov; 102, 47-50.

https://dx.doi.org/10.1016/j.earlhumdev.2016.09.007

[4] Valero L, Alhareth K, Gil S, Lecarpentier E, Tsataris V, Mignet N, Fournier T, Andrieux K. Nanomedicine as a potential approach to empower the new strategies for the treatment of preeclampsia. Drug Disov. Today. 2018 Jan 30; 23(5): 1099-1107. https://dx.doi.org/10.1016/j.drudis.2018.01.048

[5] Bosetti R. Cost-effectiveness of nanomedicine: the path to a future successful and dominant market? Nanomedicine. 2015 Jul 3; 12(10): 1851-1853. https://dx.doi.org/10.2217/nnm.15.74

[6] Witlin AG, Sibai BM. Magnesium sulfate therapy in preeclampsia and eclampsia. Obste. Gyneco. 1998 Nov; 92(5): 883-889. https://dx.doi.org/10.1016/S0029-7844(98)00277-4

[7] Harmon AC, Cornelius DC, Amaral LM, Faulkner JL, Cunningham MW, Wallace K, LaMarca, B. The role of inflammation in the pathology of preeclampsia. Clin Sci. 2016 Mar; 130(6): 409-419. https://dx.doi.org/10.1042/CS20150702

[8] Sibai BM. Diagnosis and Management of Gestational Hypertension and Preeclampsia. Obstetrics \& Gynecology, 2003 Jul; 102(1): 181-192. https://doi.org/10.1016/S0029-7844(03)00475-7

[9] Chabarria KC, Racusin DA, Antony KM, Kahr M, Suter MA, Mastrobattista J, Aagaard KM. Marijuana use and its effects in pregnancy. American Journal of Obstetrics and Gynecology, 2016 Oct; 215(4): 506.e1-506.e7. https://doi.org/10.1016/j.ajog.2016.05.044

[10] Palei AC, Spradley FT, Warrington JP, George EM, Granger JP. Pathophysiology of hypertension in preeclampsia: a lesson in integrative physiology. Acta Physiol. 2013 Jul; 208(3): 224-233. https://dx.doi.org/10.1111/apha.12106

[11] Zhou CC, Ahmad S, Mi T, Abbasi S, Xia L, Day MC, Ramin SM, Ahmed A, Kellems RE, Xia, Y. Autoantibody from women with preeclampsia induces soluble fms-like tyrosine kinase-1 production via angiotensin type 1 receptor and calcineurin/nuclear factor of activated t-cells signaling. Hypertension. 2008 Apr; 51(4): 1010-1019. https://dx.doi.org/10.1161/HYPERTENSIONAHA. 107.097790

[12] Xie H, Sun X, Piao Y, Jegga AG, Handwerger S, Ko MSH, Dey SK. Silencing or amplification of endocannabinoid signaling in blastocysts via $\mathrm{CB}_{1}$ compromises trophoblast cell migration. $J$ Biol. Chem. 2012 Sep 14; 287(38): 32288-32297. https://dx.doi.org/10.1074/jbc.M112.381145

[13] Zou S, Kumar U. Cannabinoid receptors and the endocannabinoid system: Signalling and function in the central nervous system. Int. J. Mol. Sci. 2018 Mar 13; 19(3): 833. https://dx.doi.org/10.3390/ijms19030833

[14] Stanley CP, Hind WH, O'Sullivan SE. Is the cardiovascular system a therapeutic target for cannabidiol? Brit. J. Clin. Psychol. 2013 Feb; 75(2): 313-322. https://dx.doi.org/10.1111/ j.1365-2125.2012.04351.x 
UNDERGRADUATE RESEARCH IN NATURAL AND CLINICAL SCIENCE AND TECHNOLOGY (URNCST) JOURNAL Read more URNCST Journal articles and submit your own today at: https://www.urncst.com

[15] Malinowska B, Toczek M, Pędzińska-Betiuk A, Schlicker E. Cannabinoids in arterial, pulmonary and portal hypertension-mechanisms of action and potential therapeutic significance. Brit. J. Pharmacol. 2019 May; 176(10): 1395-1411. https://dx.doi.org/10.1111/bph.14168

[16] Kumasawa K, Ikawa M, Kidoya H, Hasuwa H, SaitoFujita T, Morioka Y, Takakura N, Kimura T, Okabe M. Pravastatin induces placental growth factor (PGF) and ameliorates preeclampsia in a mouse model. P. Natl. Acad. Sci. 2011 Jan 25; 108(4):1451-1455. https://dx.doi.org/10.1073/pnas.1011293108

[17] Bilotas MA, Olivares CN, Ricci AG, Baston JI, Bengochea TS, Meresman GF. Interplay between endometriosis and pregnancy in a mouse model. PLoS ONE. 2015 Apr 27; 10(4): 1-15. https://dx.doi.org/10.1371/journal.pone.0124900

[18] Acevedo B, Perera Y, Ruiz M, Rojas G, Benítez J, Ayala M, Gavilondo J. Development and validation of a quantitative ELISA for the measurement of PSA concentrations. Clin Chim Actta. 2002 Mar; 317: 55-63. https://dx.doi.org/10.1016/S0009-8981(01)00749-5
[19] Jain RB. A recursive version of Grubbs' test for detecting multiple outliers in environmental and chemical data. Clin Biochem. 2010 Aug; 43(12): 1030-1033. https://dx.doi.org/10.1016/ j.clinbiochem.2010.04.071

[20] Yang C, Xue X, An N, Huang X-J, Wu Z-H, Ye L, Li Z-H, Wang S-J, Pan Q-J, Liang D, Liu H-F. Accelerated Glomerular Cell Senescence in Experimental Lupus Nephritis. Med. Sci. Monitor. 2018 Sept 28; 24: 6882-6891. https://dx.doi.org/10.12659/MSM.909353

[21] Whitesall SE, Hoff JB, Vollmer AP, D’Alecy LG. (2004). Comparison of simultaneous measurement of mouse systolic arterial blood pressure by radiotelemetry and tail-cuff methods. Am J Physiol. 2004 Jun; 286: 2408-2415. https://dx.doi.org/10.1152/ajpheart.01089.2003

[22] AVMA Guidelines for the Euthanasia of Animals: 2020 Edition [cited 2020 Jan 29]. Availible from: https://www.avma.org/ sites/default/files/2020-01/2020-Euthanasia-Final-117-20.pdf

\section{Article Information}

Managing Editor: Jeremy Y. Ng

Peer Reviewers: Bi-Ru Amy Yeung, Vinita Dhir

Article Dates: Received Dec 18 19; Accepted Jan 25 20; Published Feb 2620

\section{Citation}

Best MA, Wilkes RA, Zingone NMR, Farag H. Investigation into cannabidiol as a potential treatment for preeclampsia in B6D2F1 mice with placenta specific human transgene $h s F L T 1$ : A research protocol. URNCST Journal. 2020 Feb 26: 4(2). https://urncst.com/index.php/urncst/article/view/176

DOI Link: https://doi.org/10.26685/urncst.176

\section{Copyright}

(C) Madison A. Best, Rachel A. Wilkes, Nicholas M. R. Zingone, Hesham Farag (2020). Published first in the Undergraduate Research in Natural and Clinical Science and Technology (URNCST) Journal. This is an open access article distributed under the terms of the Creative Commons Attribution License (https://creativecommons.org/licenses/by/4.0/), which permits unrestricted use, distribution, and reproduction in any medium, provided the original work, first published in the Undergraduate Research in Natural and Clinical Science and Technology (URNCST) Journal, is properly cited. The complete bibliographic information, a link to the original publication on http://www.urncst.com, as well as this copyright and license information must be included.

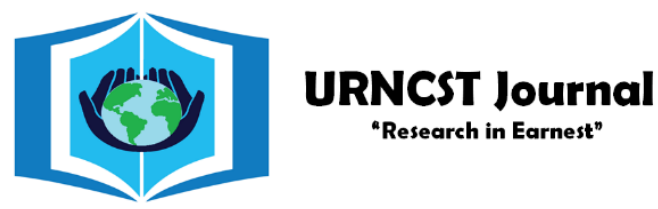
Funded by the Government of Canada

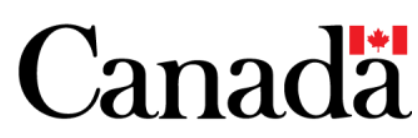

Do you research in earnest? Submit your next undergraduate research article to the URNCST Journal!

| Open Access | Peer-Reviewed | Rapid Turnaround Time | International |

| Broad and Multidisciplinary | Indexed | Innovative | Social Media Promoted |

Pre-submission inquiries? Send us an email at info@ urncst.com | Facebook, Twitter and LinkedIn: @URNCST

Submit YOUR manuscript today at https://www.urncst.com!

Best et al. | URNCST Journal (2020): Volume 4, Issue 2

Page 5 of 5

DOI Link: https://doi.org/10.26685/urncst.176 